\title{
PÕHIKOOLI I JA II ASTME ÕPILASED ARVUTIGA KIRJUTAJATENA: KAS PIKEMAAEGSEM ARVUTI KASUTAMISE KOGEMUS TAGAB PAREMAD TULEMUSED TEKSTILOOMES? ${ }^{1}$
}

\author{
ANNE UUSEN, HELIN PUKSAND
}

\begin{abstract}
Annotatsioon. Digitehnoloogia kiire areng ja koroonapandeemia on tõstatanud vajaduse hakata kasutama e-hindamist. Keele ja kirjanduse valdkonnas on möödapääsmatu hinnata ka tekstiloomeoskust. Artiklis antakse e-tasemetööde katsetuse kirjutamisosa põhjal ülevaade põhikooli I ja II astme õpilaste tekstiloomeoskuse üldistest tulemustest. Uuringus osales 249 õpilast I kooliastmest ja 251 õpilast II kooliastmest. Analüüsi tulemused näitavad I astme õpilaste nõrgemat tulemust e-kirja kirjutamise ülesandes, jutustava teksti kirjutamisel erinevusi aga ei esinenud. Digivahendite kasutamise sageduses koolis üldiselt ja emakeeletunnis ilmnesid samuti kooliastmeti erinevused. See seletab mõneti ka tekstiloome suhteliselt madalat keskmist tulemust. Nii võib järeldada, et õpilaste kirjutamisoskuse hindamiseks arvutiga kirjutatud tekstide põhjal tuleb läbi mõelda, kuidas tagada kõigile õpilastele sel tasemel arvuti kasutamise oskus, et see ei mõjutaks tekstiloome tulemust negatiivselt.
\end{abstract}

Võtmesõnad: kirjutamine, kirjutamisoskuse areng, e-hindamine, e-tasemetöö, tekstiloome, digitaalse kirjutamise oskus

\section{Sissejuhatus}

Kirjutamine on nooremate õpilaste jaoks kõige nõudlikum, keerulisem ja pikemaaegsemat harjutamist nõudev keelelise suhtluse osaoskus nii protsessi kompleksse olemuse kui selle tõttu, et tulemus, eriti kirjutamise vormilised/mehaanilised aspektid, nagu käekiri, õigekiri, punktuatsioon

\footnotetext{
Artikli valmimist on toetanud Euroopa Sotsiaalfond projekti „Kaasaegse ja uuendusliku õppevara arendamine ja kasutuselevõtt" kaudu.
} 
jms, on kõigile silmaga näha (Holliway, McCutchen 2004; Uusen 2006). Kirjutamise õppimist kirjeldatakse mitmemõõtmelise protsessina, sõltumata sellest, kas seda tehakse paberit ja pliiatsit või klaviatuuri kasutades (Berninger, Winn 2006). Kulub kümme kuni kakskümmend aastat (isikuti varieerub) küpsemist, juhendamist ja harjutamist, et edeneda algaja kirjutaja etapist kesktaseme kirjutajaks (Bereiter, Scardamalia 2013; Nippold 2004).

Käsitsi ja arvutiga kirjutamist on siiski siiani vähe võrreldud. Eestis on 5. klasside õpilaste käsitsi ja arvutiga kirjutatud tekste analüüsinud Jane Pugi (2014), kes jõudis muu hulgas järeldusele, et arvutiga kirjutatud tekstid on käsitsi kirjutatud tekstidest pikemad ja sisaldavad rohkem lauseid, kuid leksikaalse mitmekesisuse näitajates ja lausepikkuses erinevused puuduvad.

Seda, kas ja kes peaks õpetama põhikooli I ja II astme õpilastele klaviatuuri ja tekstitöötlusprogrammi kasutamist, õppekavas (PRÕK 2011) konkreetselt sätestatud ei ole ning seda ei ole tehtud ka teistes riikides (vt Mogey jt 2012; van Weerdenburg jt 2019). Siiski on põhikooli noorematel õpilastel üha enam võimalus, vajadus ja soov kasutada õppetöös arvuteid ka kirjutamiseks (Puksand, Uusen 2020). See on väga positiivne, sest arvutiga loodud kirjutiste kvaliteet on seda parem, mida tõhusam on teksti trükkimise / klaviatuuri kasutamise oskus (Goldberg jt 2003; Graham jt 2012). Lisaks on klassiõpetajad erinevates küsitlustes märkinud, et klaviatuuri kasutamise oskus on õpilaste jaoks oluline muu hulgas standardiseeritud e-testides paremate tulemuste saavutamiseks (Poole, Preciado 2016). Ka Eesti elukestva õppe strateegia 2020 (HTM 2014) üks eesmärk on Eesti haridussüsteemi üleminek e-hindamisele. Järelikult on e-tasemetööde võimalikult hea soorituse aluseks oskuslik klaviatuuri kasutamine. Seega peaks enne täielikku üleminekut e-hindamisele olema tagatud ja kontrollitud, et see oskus oleks olemas.

Endise SA Innove (praeguse Haridus- ja Noorteameti) tellimisel on Tartu Ülikooli töörühm koostanud põhikooli I ja II astme e-tasemetööde katsetestid, mille I osas tuli (ja tuleb ka edaspidi) õpilastel arvutis kirjutada kaks teksti: jutustus pildiseeria põhjal ja e-kiri. Eeltoodut arvestades on alust eeldada, et põhikooli II astme õpilaste tekstiloome tulemused on paremad kui I astme õpilastel, sest neil on olnud rohkem aega ja võimalusi arvutiga kirjutamist (ka kirjutamist üldse) teadlikult ning süsteemselt harjutada. 
Uurimuse eesmärk ongi 2019. aasta oktoobris katsetatud e-tasemetööde kirjutamisosa tulemuste põhjal välja selgitada, kas II astme õpilaste tekstiloome tulemused on paremad võrreldes I astme õpilaste omadega. Ühtlasi saab uurimistulemuste põhjal teha esmaseid järeldusi I astme õpilaste arvutiga kirjutamise oskuse kohta üldisemalt ehk vastata (lisa)küsimusele, kas ja mil moel on I astme e-tasemetöös edaspidi mõistlik tekstiloomeoskust mõõta.

\section{Teoreetiline taust}

Probleemi mõistmiseks on vaja teada teemaga seotud olulisi mõisteid ja vaatenurki. Seega anname ülevaate kirjutamise mõistest ja olemusest ning kirjutamisoskuse arengust ja uurime, missugune on arvuti, sealhulgas tekstitöötlusprogrammi pikemaaegse kasutamise (ja eeldatavasti siis ka parema kasutamisoskuse) võimalik mõju arvutiga kirjutatud tekstide tulemustele.

\subsection{Kirjutamise mõiste ja olemus}

Kirjutamist on defineeritud mitmeti:

- lugejale suunatud visuaalsete sümbolite tootmine (Bright 1995: 10-11; Sarmavuori 2003: 85);

- keelekasutusprotsess kogemusele tähenduse leidmiseks ja selle vahendamiseks (Salomon jt 2003);

- mitmetahuline ja eesmärgistatud protsess, mille käigus luuakse tähendusi ja sõnumeid ning vahendatakse neid lugejale tõlgendamiseks (Riley, Reedy 2000: 16);

- kirjutamissüsteemi või ortograafia kasutamine seonduvalt igapäevaelu ja kultuuri edasiandmisega ühelt põlvkonnalt teisele (Harris, Hodges 1995: 284);

- ideede väljendamine tähtede, sõnade, kunsti või meedia abil, miski, mis saab toimuda ainult siis, kui selleks on rakendatud mentaalseid (vaimseid) toiminguid ja protsesse (Dahl, Farnan 2000: 5-6);

- eri teadmisi ja oskusi integreeriv oskus; keelt, mõtlemist, elukogemust, tundeid, mehaanilisi tegevusi ja erinevaid strateegiaid sisaldav tegevus jne (Harris, Hodges 1995: 284; Hennings 2000: 319). 
Olgugi sõnastus autoritel erinev, on kõigil üks ühine oluline vaatenurk - kirjutamine tähendab sõnumi või tähenduse edastamist lugejale (kirjalikus vormis) (Uusen 2006). Kõigist kirjutamise definitsioonidest jääb kõlama, et tegu on mitmekihilise ja mentaalselt nõudliku tegevusega, mis eeldab kvaliteetse tulemuse saavutamiseks kirjutajalt väga paljude osaoskuste valdamist ning samaaegset kasutamist, samuti aega nende oskuste arendamiseks (Holliway, McCutchen 2004; Tichenor 1998).

\subsection{Kirjutamisoskuse areng}

Kirjutamisoskuse (kirjaliku tekstiloome) arengut käsitletakse kognitiivse arengu vaatenurgast protsessina, mille käigus edenetakse läbi kolme taseme: algaja kirjutaja tasemelt (loodud tekst on põhiliselt jutustavas vormis autori mõtete ümberütlemine) kesktaseme kirjutajaks (protsessi tulemuseks on autori mõtteprotsessi kontsentreeritud versioon), liikudes edasi kõrgtasemele (autor suudab silmas pidada nii enda kui lugeja perspektiivi) (Kellogg 2008; Myhill, Jones 2007).

Nagu öeldud, kognitiivse arengu vaatenurgast on iga perioodi läbimine pikk protsess. Olenevalt east, millal lapsed hakkavad keelt n-ö õppima, on neil 14-16aastaseks saamisel olnud kümme aastat võimalik harjutada käekirja, õigekirja, omandada vilumus nii suulise kui kirjaliku teksti loomises jne (Nippold 2004). Põhikooli I ja II astme õpilased on enamasti algaja kirjutaja tasemel. Kesktasemeni jõutakse järgneva kümne aasta jooksul. (Ericsson jt 1993; Lee, Karmiloff-Smith 1996) Kõrgtase saavutatakse heal juhul gümnaasiumi lõpuks ja/või ülikoolis õppimise ajal ning see kirjeldab pigem küpset täiskasvanud kirjutajat, kelle eesmärk on saada oskuslikuks professionaalseks kirjutajaks (Kellogg 2008; Ravid, Tolchinsky 2002). Kõrgtaseme saavutamist alles kõrgkoolis kinnitavad ka meil tehtud uuringud (vt Kerge jt 2014).

Arvatakse, et peamine takistus või piirang nende kolme taseme läbimisel (sinnani jõudmisel) on töömälu limiteeritud maht. On tõdetud, et põhilised mehaanilised oskused, nagu käekiri (arvutiga kirjutamisel klaviatuuril tippimine) ja õigekiri, kulutavad laste töömälu niigi piiratud ressursse, takistades nende võimet ladusalt keelt luua. Algklassides ongi seetõttu õige aeg õppida kirjutamisega seotud mehaanilisi oskusi, et need automatiseeruksid, vabastades seeläbi töömälu varusid kõrgema taseme 
protsesside jaoks (Graham jt 1997). Kui lapsed ei arenda soravat käekirja ja/või trükkimist (arvutiga kirjutades) enne 12aastaseks saamist piisavalt, siis nende tekstiloomeoskus ehk üldine kirjutamisoskus nõrgeneb oluliselt (Kellogg 2008).

Kokkuvõtvalt öelduna on kirjutamisoskuse arenemiseks vaja 1) töömälu, 2) suhtelist automaatsust teatud kirjutamisega seotud osaoskustes, 3) sihipärast harjutamist. Et kõik kolm komponenti on seotud ajafaktoriga - heaks kirjutajaks saadakse pikaaegse ja süsteemse õppimise ning praktiseerimise tulemusel -, võetigi uurimuse eelduseks, et II astme õpilaste tulemused tekstiloomes peaksid olema paremad kui I astme õpilaste omad.

\subsection{Arvutiga kirjutamisest}

Nii kirjutamisülesanne kui ka -vahend mõjutavad seda, milline teksti loomise strateegia valitakse ja mis on tulemus (van Waes, Schellens 2003). Üha enam kasutatakse õpetamise ja kirjutamise vahendina multimeediakeskkondi ning arvutit. Kaugõppimise ajastu on nende vahendite valdamise oskuse vajadust kõigile tõestanud. Kui multimeediakeskkondi ja arvutit kasutatakse otstarbekalt, on need õppimise vaeva väärt ning suure kasuteguriga õpetamise vahendid. Nende efektiivsus sõltub aga paljuski juhendamismeetoditest ja sellest, mil moel nende võimalusi kasutatakse (Salomon jt 2003).

Õppimise toetamise seisukohast saab arvutipõhiste tööriistade ja tarkvara abil edendada enamikku kirjutamisega seotud aspekte. Tekstitöötlusprogrammid sisaldavad näiteks grammatika ja õigekirja tööriistu, mis on üks olulisimaid funktsioone, mille abil saavad ka algajad kirjutajad kontrollida oma õigekirja, grammatikat ning sõnavalikut. Funktsioonide, nagu tekstiosade sisestamise, kustutamise ja liigutamise kasutusuuringute leiud näivad kinnitavat, et õpilased, kes kasutavad tekstitöötlusprogramme, kirjutavad pikemaid tekste, teevad vähem vigu ja rohkem tekstiparandusi (Hawisher 1988, 1989; Kozma 1991; Salomon jt 2003).

Õpetaja, kes õpetab kirjutamist arvuti abil, peaks õpetama ka tekstitöötluse põhioskusi. Mida automatiseerunum on teksti trükkimise oskus, seda paremaks on osutunud arvutiga kirjutatud tekstide põhjal saadud tulemused. Kümnest uuringust seitsmes leidis kinnitust tekstitöötlusvahendite (nt õigekirja ja grammatika kontroll, klaviatuuri valdamine) 
positiivne mõju arvutiga kirjutatud tekstidele. Kus see oli väiksem või puudus üldse, oli õpilastel vähe trükkimiskogemust või oli see algeline. Järelikult võib klaviatuuri käsitsemise oskus/osavus oluliselt mõjutada arvutiga kirjutatud tekstide kvaliteeti (van Weerdenburg jt 2019).

Eespool kirjeldatu andiski ajendi võrrelda põhikooli I ja II astmes katsetatud e-testide tekstiloomeosa tulemusi, et teha esmaseid järeldusi selle kohta, mida arvestada algkooliealistele õpilastele e-tasemetööde tekstiloomeülesannete koostamisel ning kas (II astme õpilaste) pikemaaegsem arvutil trükkimise (ja üldiselt arvuti kasutamise) kogemus tagab paremad tulemused kirjutamisoskuse osas.

\section{Materjal ja meetod}

Õpilaste oskust kirjutada arvutis hinnati katseliste e-tasemetööde tekstiloomeülesannetega. Mõlemas kooliastmes oli kaks kirjutamisülesannet: kirjaliku suhtluse ja jutustava teksti kirjutamise ülesanne. I kooliastmes pidid õpilased kirjaliku suhtluse ülesandes kirjutama sõbrale e-kirja, et kutsuda sõber AHHAA-keskuse töötuppa. II kooliastmes tuli kirjutada kiri raamatukokku, et paluda raamatu tähtaja pikendust ja uurida, kui palju maksab raamatu kaanest koopia tegemine. Teises ülesandes pidid mõlema kooliastme õpilased kirjutama jutustava teksti pildiseeria järgi, milles oli 4 pilti. I kooliastme teksti pikkus pidi olema umbes 70 sõna, II kooliastmes 100 sõna. Mõlemas kooliastmes kasutati sama pildiseeriat, kuid II kooliastme ülesanne oli nõudlikum: õpilased pidid piltide põhjal järeldama, kuidas saaks lugu edasi minna. Ülesanded olid eelnevalt testitud. Pärast eeltestimist lisati jutustava teksti tööjuhendisse eeldatav sõnade arv, kuna eeltestimisel oli I kooliastmes tekstide pikkus 4-149 sõna, II astmes aga 27-677 sõna.

Õpilased tegid tekstiloomeülesandeid eksamiinfosüsteemis EIS. Oluline on märkida, et selles süsteemis ei olnud õpilastel võimalik õigekirjakorrektorit kasutada. Mõlemas kooliastmes oli kahe teksti kirjutamiseks aega kokku 60 minutit. Katsetusel osales I kooliastmes 6 koolist 249 õpilast (3.-4. klassist), kellest 50,6\% olid poisid ja 49,4\% tüdrukud. II kooliastmes sooritas katse 20 koolist 251 õpilast (6.-7. klassist), kellest $55,8 \%$ olid poisid ja $44,2 \%$ tüdrukud.

Kõiki ülesandeid hindas kaks hindajat hindamisjuhendi järgi, mis oli mõlemas astmes ühesugune, kuid hindamisel tuli lähtuda kooliastme 
õpitulemustest. Et taseme- ja eksamitööde e-hindamise arendus üldises mõttes ei ole lõppenud ning e-hindamisele ülemineku ajakava pole avalikustatud, siis ei ole võimalik hindamisjuhendi ja oskustasemete kirjeldusi/ detaile artiklis veel avaldada.

Nii e-kirja kui jutustava teksti kirjutamise ülesandes hinnati teksti- ehk sisuloome, õigekeelsuse ja digitaalse kirjutamise oskust, kirjaliku suhtluse ülesandes ka kirjaliku suhtluse oskust. Tekstiloome all hinnati, kas tekst vastab ülesande eesmärgile, kas tekst on terviklik ja sidus ning missugune on õpilase sõnavara. Õigekeelsuse hindamisel lähtuti vastava kooliastme õpitulemustest, mis on kirjeldatud põhikooli riiklikus õppekavas (PRÕK 2011). Digitaalse kirjutamise oskuse all hinnati, kas ja kui palju teeb õpilane hooletus- ja trükivigu ning kas järgib vormistusreegleid. Kirjaliku suhtluse hindamisel vaadati, kas tekstis antakse edasi vajalik info ja arvestatakse suhtluspartneriga. Enne hindamist läbisid hindajad koolituse ja hindamise ajal said vajadusel nõu hindamisjuhilt.

Kirjutamisülesannete analüüsimisel kasutati ülesannete keskmist tulemust, omavahelist korrelatsiooni ja Cronbachi alfat. Cronbachi alfaga mõõdeti ülesannete reliaablust. Valimite keskväärtuste erinevuste statistilist olulisust mõõdeti Studenti t-testiga ( $t$-test: Two Sample Assuming Equal Variances; t-test: Two Sample Assuming Unequal Variances). Olulisuse tõenäosus on tähistatud töös $p$-ga. Olulisuse nivooks valiti 0,05 ning tähistatud on see $\alpha$-ga. Õige t-testi valemi valikuks (kas valim on võrdse või erineva dispersiooniga) tehti enne F-test (F-test: Two Sample for Variances).

\section{I ja II kooliastme õpilaste arvutis kirjutamise oskus ja digivahendite kasutamise harjumused}

Siinses peatükis analüüsitakse arvutiga kirjutatud kaht teksti: e-kirja ja pildiseeria järgi kirjutatud jutustavat teksti. Seejärel hinnatakse õpilaste digivahendite kasutamise oskust, lähtudes õpilaste endi hinnangutest.

\subsection{Arvutis kirjutamise oskus}

Kõigepealt kontrolliti, kas ülesanded mõõtsid seda, mida taheti mõõta. Ülesannete sisemine reliaablus oli suur (Cronbachi alfa oli üle 0,7) kolmel ülesandel: I astme kirjaliku suhtluse ülesandel (Cronbachi alfa oli 0,76) ja II astme mõlemal ülesandel (Cronbachi alfa oli vastavalt 0,79 ja 0,74 ). 
I astme jutustava teksti kirjutamise ülesande reliaablus jäi vaid pisut alla 0,7 (Cronbachi alfa oli 0,68). Jutustava teksti kirjutamise ja kirjaliku suhtluse ülesande omavaheline korrelatsioon oli I kooliastmes 0,48 ja II kooliastmes 0,62, mis näitab, et II kooliastmes mõõtsid kirjutamisülesanded samasuguseid oskusi paremini kui I kooliastmes. Seega võib järeldada, et ülesanded olid usaldusväärsed ja mõõtsid seda, mida eeldati.

Kirjaliku suhtluse ehk e-kirja ülesande sooritasid ootuspäraselt paremini II kooliastme õpilased - keskmine sooritusprotsent oli II astme õpilastel 70\% ja I astme õpilastel 61\%. Erinevus on ka statistiliselt oluline ( $\mathrm{p}=0,00<\alpha=0,05)$. Mõlemas kooliastmes oli tüdrukute sooritus parem kui poistel: I kooliastmes tüdrukutel $64,2 \%$ ja poistel $58,5 \%$, II kooliastmes vastavalt 75,7\% ja 66\%. Jutustava teksti kirjutamisel aga õppeastmeti erinevusi ei ilmnenud, sest nii I kui II kooliastme õpilaste keskmine sooritusprotsent oli 53\%. Tüdrukud näitasid ka jutustava teksti kirjutamisel kõrgemaid tulemusi kui poisid: I kooliastmes saavutasid tüdrukud keskmiselt 57,3\% ja poisid 48,7\% maksimumist, II kooliastmes oli tüdrukute keskmine tulemus $58,6 \%$ ja poistel $47,9 \%$.

Järgnevalt võrreldi õpilaste tulemusi erinevate aspektide põhjal. Kuna kirjanduse väitel (vt Goldberg jt 2003; Graham jt 2012) sõltub arvutis kirjutatud teksti kvaliteet arvuti kasutamise oskusest, siis oli üheks hinnatavaks aspektiks digitaalse kirjutamise oskus. I kooliastme õpilaste sooritus oli mõlema teksti puhul suhteliselt sarnane: e-kirja ülesandes oli digitaalse kirjutamise oskuse keskmine tulemus $56 \%$ ja jutustava teksti ülesandes 58\% ning erinevus ei olnud ka statistiliselt oluline $(\mathrm{p}=0,189$ $>\alpha=0,05)$. II astme õpilastel oli aga kirjaliku suhtluse ülesandes digitaalse kirjutamise oskuse aspekt oluliselt kõrgem kui jutustava teksti ülesandes, vastavalt $70 \%$ ja $57 \%(\mathrm{p}=0,00<\alpha=0,05)$. Viimane võis olla tingitud tekstide erinevast pikkusest, kuid see ei seleta I kooliastme sarnast tulemust.

Õigekeelsuse aspekt oli mõlemas kooliastmes kõrgem kirjaliku suhtluse ülesandes: I astmes vastavalt $71 \%$ ja $50 \%$, II astmes $75 \%$ ja $44 \%$. Siit ilmneb selgelt teksti pikkuse mõju, kuna pikemas tekstis teevadki õpilased rohkem vigu (vt Uusen 2006). Lisaks tegid II kooliastme õpilased jutustavas tekstis rohkem õigekeelsusvigu kui I kooliastme õpilased, mida võib seletada hindamisega. Õigekeelsuse hindamisel lähtuti kooliastmes õpitust - veaks ei loetud neid keelendeid, mida vastavas kooliastmes ei 
ole käsitletud. Hindajad tõid ka välja, et õigekeelsusvigu oli kohati keeruline eristada digitaalse kirjutamise vigadest, kuna raske oli vahet teha, kas näiteks puuduv täht viitas trükkimise veale või ei osanud õpilane sõna õigesti kirjutada.

Kirjalikes tekstides hinnati ka sisu ehk tekstiloomeoskust. Sisu poolest olid samuti mõlemas kooliastmes paremad kirjaliku suhtluse ülesande vastused: I kooliastmes 56\% ja 53\% $(\mathrm{p}=0,113>\alpha=0,05)$ ning II kooliastmes $61 \%$ ja $57 \%(p=0,02<\alpha=0,05)$. Kuigi erinevused ei olnud eriti suured, siis II astmes oli erinevus statistiliselt oluline.

E-kirjades hinnati ka kirjaliku suhtluse oskust. Siit tuleb välja oluline erinevus $(\mathrm{p}=0,00<\alpha=0,05)$ kooliastmete vahel: I kooliastmes oli kirjaliku suhtluse tulemus keskmiselt 63\%, II kooliastmes aga 75\%. See võib seletada erinevust, miks kirjaliku suhtluse ülesande keskmine tulemus oli II kooliastmes oluliselt parem kui I astmes (70\% vs. $61 \%$; $p=0,00<$ $\alpha=0,05)$. II kooliastme õpilased on ilmselgelt puutunud e-kirjade kirjutamisega rohkem kokku, kuna e-kirja kirjutamine on kohustuslik teema II kooliastme ainekavas (PRÕK, 2011).

\section{2. Õpilaste digipädevus nende endi hinnangul}

I ja II kooliastme õpilaste digivahendite kasutamise harjumuste kohta saab järeldusi teha tagasisideküsimustiku põhjal, mille õpilased täitsid pärast ülesannete tegemist. Eesmärk oli teada saada, kui palju õpilased päevas enda arvates digivahendeid kasutavad. Selleks vastasid õpilased valikvastustega küsimusele „Kasutan digivahendeid keskmiselt iga päev alla 1 tunni / 1-2 tundi / 2-3 tundi / 3-4 tundi / üle 4 tunni“. Digivahendite kasutamise aeg erines kooliastmeti päris palju. I kooliastmes oli rohkem neid õpilasi, kes kasutasid digivahendeid kas alla 1 tunni (29\%) või 1-2 tundi (38\%), kuid II kooliastmes kasutas digivahendeid alla 1 tunni vaid 5\% õpilastest ja 1-2 tundi $26 \%$ vastanutest. Samas 3-4 tundi või üle 4 tunni kasutas digivahendeid 16\% I astme õpilastest, kuid 35\% II astme õpilastest.

Et saada teada, mis digivahendeid õpilased enda arvates kasutavad, pidid nad vastama valikvastustega küsimusele „Kasutan vähemalt kord nädalas lauaarvutit / sülearvutit / tahvelarvutit / nutitelefoni / e-lugerit / ei kasuta ühtki digivahendit“. Õpilaste vastuseid illustreerib joonis 1 . 


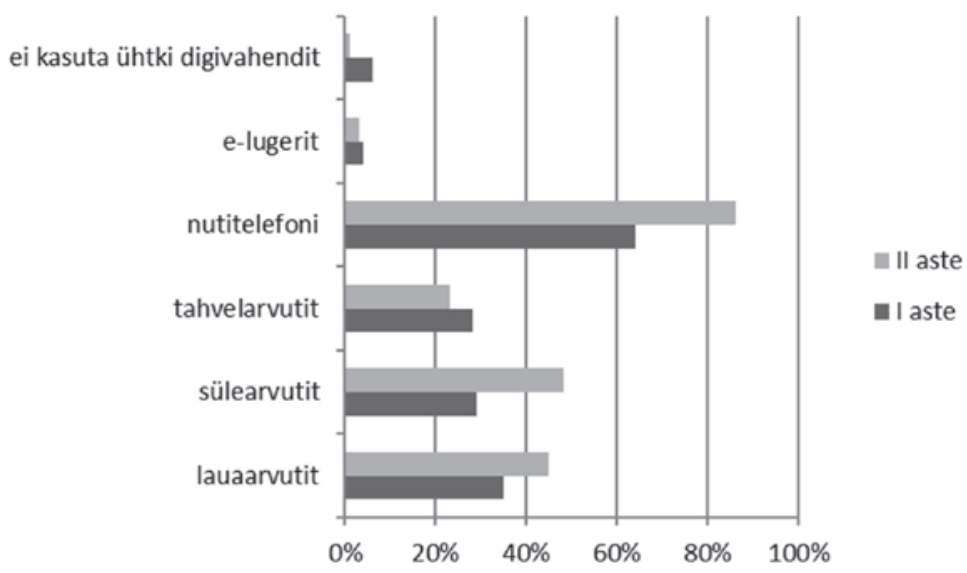

Joonis 1. Digivahendite kasutamine vähemalt kord nädalas

Kõige enam kasutati nutitelefoni: I astmes vastas nii $64 \%$ ja II astmes $86 \%$ õpilastest. Kasutati ka lauaarvutit (I astmes 35\% ja II astmes 45\%), sülearvutit (I astmes 29\% ja II astmes 48\%) ning tahvelarvutit (I astmes $28 \%$ ja II astmes 23\%). Oluliselt vähem kasutati e-lugerit (I astmes 4\% ja II astmes 3\%). Oma sõnul ei kasutanud ühtki digivahendit 6\% I astme ja vaid $1 \%$ II astme õpilastest.

Alates 2014. aastast on põhikooli riiklikus õppekavas (PRÕK 2011) ühe pädevusena kirjeldatud ka digipädevust, mistõttu tuleks koolis digivahendeid kasutada juba esimestest klassidest alates. Hindamaks, kui sageli õpilased enda arvates õppimiseks digivahendeid kasutavad, esitati kolm valikvastustega küsimust: 1) „Kasutan koolis õppimiseks digivahendeid igas tunnis / 2-3 korda nädalas / 2-3 korda kuus / harvem / ei kasuta üldse“; 2) „Kasutan emakeele õppimiseks digivahendeid igas tunnis / 2-3 korda nädalas / 2-3 korda kuus / harvem / ei kasuta üldse“; 3) „Kasutan kodus õppimiseks digivahendeid iga päev / 2-3 korda nädalas / 2-3 korda kuus / harvem / ei kasuta üldse“. Kui sageli õpilased enda arvates õppimiseks digivahendeid kasutasid, illustreerib joonis 2 . 


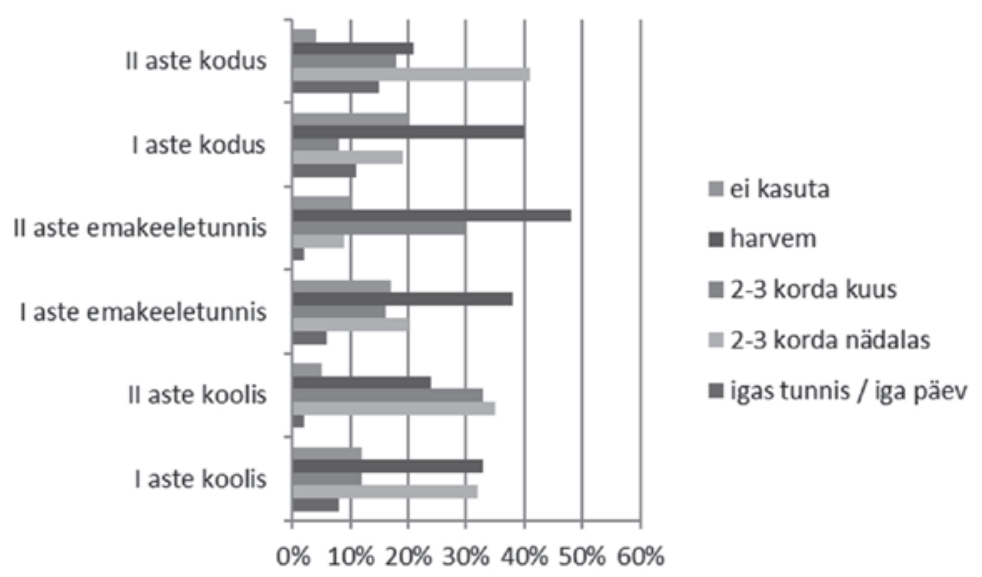

Joonis 2. Digivahendite kasutamine õpilaste hinnangul

Digivahendeid kasutati I kooliastmes õppimiseks harvem kui II kooliastmes. Üldse ei kasutanud või harvem kui 2-3 korda kuus kasutasid digivahendeid koolis õppimiseks 45\% I astme õpilastest ja 29\% II astme õpilastest. Emakeeletunnis kasutati digivahendeid aga veelgi vähem: üldse ei kasutanud või harvem kui 2-3 korda kuus kasutas digivahendeid emakeeletunnis 55\% I astme ja 58\% II astme õpilastest. Kodus õppimisel tuleb aga välja suurem erinevus kooliastmete vahel: $60 \%$ I kooliastme õpilastest ei kasutanud digivahendeid õppimiseks üldse (20\%) või kasutas harvem kui 2-3 korda kuus (40\%), II kooliastmes aga ei kasutanud kodus õppides üldse digivahendeid vaid 4\% õpilastest või kasutas harvem kui 2-3 korda kuus $21 \%$ õpilastest. Koolis kasutasid digivahendeid õppimiseks 2-3 korda nädalas 32\% I astme õpilastest ja 35\% II astme õpilastest, emakeeletunnis aga vaid 20\% I astme ja 9\% II astme õpilastest. Kui edaspidi soovitakse õpilaste kirjutamisoskust hinnata arvutis kirjutamise kaudu, siis tuleb kindlasti läbi mõelda, kuidas kõik õpilased saaksid koolist kaasa ka arvuti, sh klaviatuuri kasutamise oskuse.

Kirjutamisel eelistasid nii I kui II kooliastme õpilased kasutada arvutit (vastavalt 44\% ja 49\%). Umbes kolmandik mõlema astme õpilastest väitis, et neil ei ole vahet, kas kirjutada käsitsi või arvutis (32\% ja 35\%). Arvutis kirjutamine on õpilase jaoks lihtsam (Puksand, Uusen 2020), mistõttu on tulemus igati loogiline. 


\section{Kokkuvõte ja järeldused}

Täiskasvanud elanikkonnast enamik ei kujuta enam igapäevast elu ilma digi- ja nutivahendite kasutamise oskuseta ettegi ning suur osa tekstidest, mida on ühiskonnas edukalt toimimiseks vaja, kirjutatakse arvutiga. Ka kool ei saa siin olla erandiks. Eesti elukestva õppe strateegia 2020 (HTM 2014) näebki muu hulgas ette järkjärgulise ülemineku e-hindamisele kõigis kooliastmetes ja enamikus ainetes, kaasa arvatud emakeeles.

Põhikooli II astmes on eesti keele emakeelena tasemetöö olnud EISi keskkonnas juba viis aastat (alates 2016. aastast), aga seni pole see sisaldanud tekstiloomeülesandeid. I astmes on tasemetöö olnud paberil. Ilmselt osalt ka seetõttu, et pole olnud selget arusaama, kas ja kes peaks õpetama õpilastele arvuti - kitsamalt klaviatuuri ning tekstitöötlusprogrammi(de) kasutamist sellisel tasemel, et e-keskkonnas edukalt toime tulla.

Keele ja kirjanduse valdkonnas e-tasemetööde katsetamise tulemusena tekkiski huvi ja võimalus saada esmased andmed selle kohta, kuidas põhikooli I ja II astme õpilased arvutis kirjutamisega toime tulevad ning kas I astme õpilaste tekstiloome tulemused on oluliselt kehvemad, sest nad on koolis arvutiga kirjutamist vähem harjutanud. Kirjutatud tekstides (e-kiri ja jutt pildiseeria põhjal) hinnati mitut aspekti: digitaalse kirjutamise ja kirjaliku suhtlemise oskust, õigekeelsust ning sisu.

Selgus, et kirjaliku suhtluse ehk e-kirja ülesande sooritasid II kooliastme õpilased oluliselt paremini kui I astme õpilased, aga jutustava teksti kirjutamisel erinevusi ei ilmnenud. See kinnitab kirjandusallikatele tuginevat väidet, et ka kirjutamisülesanne mõjutab tekstiloomestrateegia valikut ja tulemust (van Waes, Schellens 2003). Seda aluseks võttes ei saa katsetuse põhjal teha paraku pädevaid järeldusi I astme õpilaste tekstitöötlusprogrammi kasutamise oskuse kohta, sest on üldiselt teada, et algajad kirjutajad saavadki jutustava tekstiga paremini hakkama (Myhill, Jones 2007). Põhjustena tuuakse välja, et jutustamine on neile keelearengu seisukohast omasem ja koolis kirjutatakse kõige sagedamini just jutte (eriti algklassides). Sama tendents ilmnes ka paberil kirjutatud tekstide põhises uurimuses (Uusen 2006).

Tõsiasi, et õigekeelsuse paremaid tulemusi e-kirjades mõjutab ilmselt teksti pikkus (vt ka Uusen 2006), annab põhjuse e-testide edasise arenduse käigus mõelda õigekeelsuse hindamise juhendi muutmise peale: õigekirjavigu oleks õigem arvestada sõnade ja vigade arvu suhtena (kui palju on tekstis õigekirjavigu ühe sõna kohta), mitte loendades vigade üldarvu. 
Oletus, et I astme õpilaste oskus kasutada tekstitöötlusprogrammi ja käsitseda klaviatuuri on viletsam kui põhikooli II astme õpilastel, tugines e-tasemetöö lõpus oleva küsitluse vastuste analüüsile, millest selgus, et õpilaste arvutiga kirjutamise kogemus nii koolis kui kodus on kooliastmeti küllaltki erinev. Siiski erines digitaalse kirjutamise aspekt kooliastmeti vaid e-kirja kirjutamisel, seevastu jutustava teksti kirjutamisel I ja II kooliastme tulemuste vahel erinevusi ei olnud. Mõnevõrra üllatuslik oli aga, et kui üldse ei kasutata koolis õppimiseks arvutit 45\% I astme ja $29 \%$ II astme õpilaste hinnangul, siis emakeeletunnis ei kasutata arvutit 55\% I ja 58\% II astme õpilaste arvates. Teades, et põhikooli II astmes annab emakeelt sageli aineõpetaja, võib sellest tingimisi järeldada, et klassiõpetajad kasutavad emakeeletunnis arvutit rohkem kui teiste ainete tundides ja enam kui aineõpetajad. Siiski ei kajastu digivahendite vähene kasutamine koolis õpilaste tulemustes, kuna jutustava teksti puhul oli digitaalse kirjutamise oskus I ja II kooliastmes sarnane (58\% ja 57\%).

Kokkuvõtteks tuleb tõdeda, et kuna kirjutise kvaliteeti (pole vahet, kas see on valminud arvutis või paberil) mõjutavad paljud tegurid, ei saa kõnealuse e-tasemetööde katsetuse põhjal kindlalt väita, et põhikooli I astme õpilaste klaviatuuri ning tekstitöötlusprogrammi kasutamise oskus oleks põhikooli II astme õpilaste omast nii palju viletsam, et mõjuks tekstiloomeülesannete täitmisele pärssivalt. Pigem saab järeldada, et keele ja kirjanduse valdkonnas peab e-hindamisele täieliku ülemineku eelduseks olema veendumus, et õpilastel on esimestest klassidest alates võimalik regulaarselt ning süsteemselt õppida klaviatuuril õigesti ja sujuvalt trükkima, kasutades igapäevaselt tekstitöötlusprogramme ning kirjutades (nii arvutiga kui paberil) eri liike tekste. Eelöeldut toetab teadmine, et pea pooled mõlema astme õpilastest eelistavad ise kirjutada pigem arvutis ning lisaks kolmandikul pole vahet, kumb vahend kirjutamiseks valida. Ühtlasi aitaks tekstitöötluse teadlik õpetamine kaasa ka teiste e-testide edukamale sooritamisele.

Edaspidistes uuringutes võiks siinses artiklis kirjeldatud katsetuse raames loodud tekste analüüsida teksti kvaliteedinäitajate põhjal ning võrrelda arvutiga kirjutatud tekste käsitsi kirjutatud tekstidega, et seeläbi saada mitmekihilisemat infot e-hindamisele üleminekuks. 


\section{Kirjandus}

Bereiter, Carl, Marlene Scardamalia 2013. The Psychology of Written Composition. New York, London: Routledge. https://doi.org/10. 4324/9780203812310

Berninger, Virginia, William D. Winn 2006. Implications of advancements in brain research and technology for writing development, writing instruction, and educational evolution. - Handbook of Writing Research. Ed. by Charles A. MacArthur, Steve Graham, Jill Fitzgerald. New York: Guilford Press, 96-114.

Bright, Robin 1995. Writing Instruction in the Intermediate Grades: What Is Said, What Is Done, What Is Understood. Newark: IRA Publications.

Dahl, Karin L., Nancy Farnan 2000. Childrens's Writing: Perspectives from Research. Newark: IRA.

Ericsson, Karl, Ralf T. Krampe, Clemens Tesch-Roemer 1993. The role of deliberate practice in the acquisition of expert performance. - Psychological Review 100 (3), 363-406. http://dx.doi.org/10.1037//0033295X.100.3.363

Goldberg, Amie, Michael Russell, Abigail Cook 2003. The effect of computers on student writing: A meta-analysis of studies from 1992 to 2002. - Journal of Technology, Learning and Assessment 2 (1), 3-51.

Graham, Steve, Virginia Berninger, Robert D. Abbott, Silvia P. Abbott, Dianne Whitaker 1997. Role of mechanics in composing of elementary school students: A new methodological approach. - Journal of Educational Psychology 89 (1), 170-182. http://dx.doi.org/10.1037/00220663.89.1.170

Graham, Steve, Debra McKeown, Sharlene Kiuhara, Karen R. Harris 2012. A meta-analysis of writing instruction for students in the elementary grades. - Journal of Educational Psychology 104 (4), 879-896. http:// dx.doi.org/10.1037/a0029185

Harris, Theodore L., Richard E. Hodges 1995. The Literacy Dictionary. The Vocabulary of Reading and Writing. Newark: IRA.

Hawisher, Gail E. 1988. Research update: Writing and word processing. Computer and Composition 5 (2), 7-27. https://doi.org/10.1016/87554615(88)80002-1

Hawisher, Gail E. 1989. Research and recommendations for computers and compositions. - Critical Perspectives on Computers and Composition Instructions. Ed. by Gail E. Hawisher \& Cynthia L. Selfe. New York: Teachers College Press, 44-69.

Hennings, Dorothy Grant 2000. Communication in Action: Teaching LiteratureBased Language Arts. 7th ed. Boston: Houghton Mifflin Company. 
Holliway, David R., Deborah McCutchen 2004. Audience perspective in young writers' composing and revising. - Revision Cognitive and Instructional Processes. Ed. by Linda Allal, Lucile Chanquoy, Pierre Largy. (= Studies in Writing 13.) Boston, Dordrecht, New York: Springer, 87-101. http:// dx.doi.org/10.1007/978-94-007-1048-1_6

HTM 2014 = Haridus- ja Teadusministeerium 2014. Eesti elukestva õppe strateegia 2020. https://www.hm.ee/sites/default/files/strateegia2020.pdf (25.10.2020).

Kellogg, Ronald T. 2008. Training writing skills: A cognitive developmental perspective. - Journal of Writing Research 1 (1), 1-26. http://dx.doi. org/10.17239/jowr-2008.01.01.1

Kerge, Krista, Hille Pajupuu, Pilvi Alp, Halliki Põlda, Anne Uusen 2014. Towards sophisticated writing. - Proceedings of the Tallinn University Institute of Estonian Language and Culture 16. Ed. by Krista Kerge. Tallinn: Tallinna Ülikooli Kirjastus, 103-115.

Kozma, Robert B. 1991. Computer-based writing tools and the cognitive needs of novice writers. - Computers and Composition 8 (2), 31-45. https:// doi.org/10.1016/8755-4615(91)80046-G

Lee, Kang, Anette Karmiloff-Smith 1996. The development of external symbol systems: The child as a notator. - Perceptual and Cognitive Development. Ed. by Rochel Gelman, Terry Kit-Fong Au. London: Academic Press, 185-211. https://doi.org/10.1016/B978-012279660-9\%2F50024-5

Mogey, Nora, John Cowan, Jessie Paterson, Mike Purcell 2012. Students' choices between typing and handwriting in examinations. Active Learning in Higher Education 13 (2), 117-128. https://doi. org/10.1177\%2F1469787412441297

Myhill, Debra, Susan Jones 2007. More than just error corrections: Students' perspectives on their revision processes during writing. - Written Communication 24 (4), 323-343. https://doi.org/10.1177\%2F0741088307305976

Nippold, Marilyn A. 2004. Research on later language development: International perspectives. - Language Development Across Childhood and Adolescence. Ed. by Ruth A. Berman. (= Trends in Language Acquisition 3.) Amsterdam: John Benjamins Publishing Company, 1-8. https://doi. org/10.1075/tilar.3.04nip

Poole, Dawn M., Monique K. Preciado 2016. Touch typing instruction: Elementary teachers' beliefs and practices. - Computers \& Education 102, 1-14. https://doi.org/10.1016/j.compedu.2016.06.008

PRÕK 2011 = Põhikooli riiklik õppekava. Riigi Teataja, RT I 14.01.2011, 1. https://www.riigiteataja.ee/akt/114022018008 (10.11.2020).

Pugi, Jane 2014. Arvutiga ja käsitsi kirjutatud tekstide võrdlus 5. klassides. Magistritöö. Tallinn: Tallinna Ülikool. 
Puksand, Helin, Anne Uusen 2020. Põhikooli I astme õpilaste valmisolek ja suutlikkus teha emakeele e-tasemetööd. - Emakeele Seltsi aastaraamat 65. Peatoim. Mati Erelt. Emakeele Selts. Tallinn: EKSA, 192-205. http:// dx.doi.org/10.3176/esa65.08

Ravid, Dorit, Liliana Tolchinsky 2002. Developing linguistic literacy: A comprehensive model. - Journal of Child Language 29 (2), 417-447. http:// dx.doi.org/10.1017/S0305000902005111

Riley, Jeni, David Reedy 2000. Developing Writing for Different Purposes: Teaching about Genre in the Early Years. London: SAGE Publications. http://dx.doi.org/10.4135/9781446219515

Salomon, Gavriel, Ely Kosminsky, Merav Asaf 2003. Computers and writing. - Handbook of Children's Literacy. Ed. by Terezinha Nunes, Peter Bryant. London: Kluwer, 409-442.

Sarmavuori, Katri 2003. Alkuaskelet äidinkieleen ja kirjallisuuteen. Helsinki: Valopaino.

Tichenor, Stuart 1998. Writing and computer skills: Students need more time! Opinion Papers. Oklahoma State University.

Uusen, Anne 2006. Põhikooli I ja II astme õpilaste kirjutamisoskus. (= Tallinna Ülikooli sotsiaalteaduste dissertatsioonid 19.) Tallinn: Tallinna Ülikooli Kirjastus.

Van Waes, Luuk, Peter J. Schellens 2003. Writing profiles: The effect of the writing mode on pausing and revision patterns of experienced writers. - Journal of Pragmatics 35 (6), 829-853. https://doi.org/10.1016/ S0378-2166(02)00121-2

Van Weerdenburg, Marjolijn, Mariëtte Tesselhof, Henny van der Meijden 2019. Touch-typing for better spelling and narrative-writing skills on the computer. - Journal of Computer Assisted Learning 35 (1), 143-152. https://doi.org/10.1111/jcal.12323

Anne Uusen

Haridusteaduste instituut

Tallinna Ülikool

Narva mnt 25

10120 Tallinn

uusen@tlu.ee
Helin Puksand

Eesti ja üldkeeleteaduse instituut

Tartu Ülikool

Jakobi 2

51014 Tartu

helin.puksand@ut.ee 


\title{
1st and 2nd stage students of basic school as writers by computer: does a longer-term computer use experience guarantee better results in text creation?
}

\author{
ANNE UUSEN, HELIN PUKSAND
}

The Estonian Lifelong Learning Strategy 2020 (HTM 2014) stipulates, among other things, that the Estonian education system will switch to e-assessment at all school levels. It is also unavoidable to assess text creation skills in language and literature. The article provides an overview of the general results of students' computer-written texts based on the text creation part of the primary school (stage I and II) e-tests, tested in October 2019. A previous quick analysis of the survey revealed that primary school students had fewer experiences using word processing programs at school. A literature review shows that this can most likely be an obstacle to achieving good results in the text creation part of e-tests. The analysis results described in this article showed that lower grade students performed worse on the task of writing an e-mail. However, there were no differences in the writing of narrative texts. The most significant differences were in the written communication skills assessed in the e-mails; the other indicators were relatively similar. There were also considerable differences in the frequency of using digital equipment at school in general and in mother tongue lessons. Low use of digital tools also explains the overall relatively low averages in text creation outcomes. However, it does not necessarily support the assumption made about lower word processing skills of lower-stage students. The research results lead to the conclusion that if we want to assess students' writing skills based on computer-written texts, it is necessary to consider how to ensure that all students have achieved sufficient computer skills so as not to negatively affect text creation.

Keywords: writing, development of writing skills, e-assessment, low stake assessment e-tests, text creation, digital writing skills 